\title{
The Study of the Effect of Two-Sided Variable Trends on the Occurrence of Hypertension
}

\author{
${ }^{1}$ Marniati, ${ }^{2}$ Teuku Muliadi, ${ }^{2}$ Itza Mulyani, ${ }^{2}$ Enda Silvia Putri, ${ }^{2}$ Khairunnas \\ ${ }^{1}$ Faculty of Public Health, Universitas Teuku Umar, Indonesia \\ ${ }^{2}$ Nutrition Department, Faculty of Public Health, Universitas Teuku Umar, Indonesia \\ Coresponding author: Marniati, Marniati@utu.ac.id \\ Co-author: MM: Marniati@utu.ac.id, TM: teukumuliadi@utu.ac.id, IM: itzamulyani@utuacid, ESP:Endasilviaputri@utu.ac.id, KK: \\ khainunnas@ac.id
}

Submitted:08/02/2021 Revised: 01/04/2021 Accepted: 01/04/2021 Published online: 04/06/2021

doi: https://doi.org/10.35308/j-kesmas.v7i2.1646. How to cite this article: How Marniati,Muliadi,T.,Mulyani,I.,Putri, E.S \& Khairunnas. (2021). The Study of the Effect of Two-Sided Variable Trends on the occurrence of Hypertension. J-Kesmas: Jurnal Fakultas Kesehatan Masyarakat (The Indonesian Journal of Public Health).8(1): 1-6.

\begin{abstract}
Hypertension is an excessively raised blood pressure condition that can cause serious health complications and increase the risk of heart disease, stroke, and sometimes death. The problem with hypertension cases has experienced a significant fluctuation from 2014 as many as 95 cases, increasing in 2015 to 105 cases. The survey results show that hypertension that occurs in the community is caused by family history and does not pay attention to the type of food eaten. Hypertension in the community at the Meureubo Community Health Center, Meureubo District, West Aceh Regency. This study was an analytical survey with a cross-sectional design which was conducted in December 2016 with a sample of 51 people, analyzed using univariate and bivariate, then tested with chi-square. The results showed that there was an effect of genetics and lifestyle on the incidence of hypertension as evidenced by the value of P. value $<\alpha=0.05$. For the PUSKESMAS to increase motivation in the community by suggesting consuming healthy foods, exercising regularly, to achieve the expected healthy life.
\end{abstract}

Keywords: Society; Hypertension; Genetics; Lifestyle.

\section{Introduction}

Health is the most important thing for humans, with health, humans can carry out all activities. Maintaining personal health can be done by maintaining a clean environment, consuming healthy food, exercising regularly so that diseases that can attack do not arise. Also, the government has provided health services. This health service is urgently needed by people who are stricken with the disease. (Martin Gómez. A, 2019). High blood pressure is one of the main risk factors for cardiovascular disease (Tagle. R, 2018).

Hypertension is known as high blood pressure, which is a disorder in which the blood vessels are subjected to constant high pressure, which can damage them. Every time the heartbeats, it pumps blood into the veins, which carry blood to all parts of the body. Blood pressure is the force that blood exerts against the walls of the vessels (Arteries) when they are pumped by the heart. The higher the voltage, the more effort the heart has to do to pump (WHO, 2020). In today's world, hypertension is one of the most common diseases affecting human health, being an important pathology and risk factor for other diseases, so health intervention strategies should be aimed at prevention or primary and secondary or developmental events. In research (Alfonso Prínce, J. C et al., 2017) the World Health Organization, carrying out a community project, in which Cuba was included because of sanitation outcomes, the First National Program for the Prevention and Control of Arterial Hypertension later appeared in the Ministry of Public Health. Currently coordinated by the organization and the Ministry of Health, the entity's Health Intervention Program is being implemented in Matanzas province, at a polyclinic in the main municipality.

One of the main problems in public health in Indonesia and the world is non-communicable diseases. For example, hypertension, an estimated $80 \%$ increase in cases of hypertension, especially in developing countries in 2025 from a total number of 639 million cases in 2000. This number is estimated to increase to 1.15 billion cases in 2025. This prediction is based on the number of hypertension sufferers and the current population growth (Ardiansyah, 2012). Hypertension is a disease with various medical conditions. In most patients the pathological etiology is unknown. In general, 
essential hypertension is not caused by a single factor, but due to various interrelated factors. One of the factors most likely to be related to the emergence of essential hypertension is genetic factors because it is often hereditary in a family. Hypertension is a disease that arises because of the interaction of various risk factors. The relative risk of hypertension depends on the number and severity of controlled factors such as stress, nutritional obesity, and lifestyle, all uncontrollable risk factors such as genetics, age, gender, and ethnicity (Giuliani, C et al, 2018).

High blood pressure or hypertension is a disease characterized by an increase in blood pressure that exceeds normal. Hypertension often results in dangerous conditions because its existence is often unconscious and often does not cause significant complaints; until one day there are complications of the heart, brain, kidneys, eyes, blood vessels, or other vital organs. However, hypertension is strongly influenced by the food consumed by the public. A healthy lifestyle and a healthy diet are the right choices to keep yourself free from hypertension. Everything is done continuously, it must not be temporary. Once we guard ourselves by not following a healthy lifestyle, we are sure to be susceptible to hypertension and other diseases (Zilbermint et al., 2019).

People with hypertension have twice the risk of coronary heart disease and a higher risk of getting a stroke than those who do not have hypertension. If untreated, approximately half of people with hypertension will die from stroke and 10.0\% -15.0\% will die due to kidney failure, control of blood pressure is very important, which is expected to reduce mortality due to cardiovascular disease and stroke significantly. Lifestyle is an important risk factor for hypertension in a person, including young adults (21-40 years). Increased hypertension is influenced by an unhealthy lifestyle. Things that include an unhealthy lifestyle, including smoking, lack of exercise, eating less nutritious food, and stress (Nisa, 2012).

Losing weight, exercising more, eating better, and learning to stimulate a relaxation response can all lead to fundamental physical changes and improve blood pressure. This method also keeps us from high blood sugar and cholesterol levels, improves the flexibility of arteries, and improves physical and emotional health is one of the ways of a good lifestyle to avoid hypertension. This unhealthy lifestyle is a bad habit, intentionally or unintentionally, and will hurt the body. The things that cause an unhealthy lifestyle include smoking, obesity, a lazy lifestyle (Lack of movement), excess salt, caffeine, alcohol use, and stress.

World Health Organization (WHO) Figures estimate, the number of people with hypertension will continue to increase in line with the growing population. By 2025, it is projected that around 29 percent of the world's population will be affected by hypertension. Data from the WHO Global Status Report on Noncommunicable Disease 2010 from those who do not suffer from hypertension, if not treated, approximately half of hypertension sufferers will die from stroke and $10.0 \%-15.0 \%$ will die from kidney failure, so control blood pressure is a very important thing which is expected to reduce mortality due to cardiovascular disease and stroke significantly.

Lifestyle is an important risk factor for hypertension in a person, including young adults (2140 years). Increased hypertension is influenced by an unhealthy lifestyle. Things that include an unhealthy lifestyle, including smoking, lack of exercise, eating less nutritious food, and stress (Baudrand. R \& Vaidya. A, 2018).

\section{Methods}

This type of research is an analytical survey with a cross-sectional approach which was conducted in March 2016. The population in this study were hypertension patients at the health center, West Aceh district, with a sample of 51 people. Data were analyzed using univariate and bivariate, then tested using the chi-square

\section{Results}

\section{Univariat}

Respondents Frequency Distribution Based on Genetics on the Occurrence of Hypertension

Table 1. Frequency of genetics

\begin{tabular}{lcc}
\hline Gennetics & Frequency $(\mathrm{n})$ & Percentage $(\%)$ \\
\hline There is & 30 & 58,8 \\
No & 21 & 41,2 \\
\hline Total & 51 & 100 \\
\hline
\end{tabular}

Table 2. Frequency of Lifestyle

\begin{tabular}{lcc}
\hline Lifestyle & Frequency (n) & Percentage (\%) \\
\hline Good & 23 & 45,1 \\
Not Good & 28 & 54,9 \\
\hline Total & 51 & 100 \\
\hline
\end{tabular}


Table 3. Frequency of Hypertension

\begin{tabular}{lcc}
\hline Hypertension & Frequency (n) & Percentage (\%) \\
\hline Past & 34 & 66,7 \\
New & 17 & 33,3 \\
\hline Total & 51 & 100 \\
\hline
\end{tabular}

\section{Bivariate}

\section{Analysis Genetic}

According to the table 4 below, respondents who have had hypertension for a long time are more likely to find respondents whose parents are also hypertensive $(86.7 \%)$, compared to those whose parents are not hypertensive. On the other hand, respondents who have recently experienced hypertension are more likely to find respondents whose parents do not have hypertension $(61.9 \%)$. The statistical results obtained (P-value $=0.001<\alpha=$ 0.05 ) so that it is described that there is a significant influence of genetic factors on the occurrence of hypertension at Meureubo, West Aceh Regency. Based on the results of OR 10.5, it can be concluded that respondents who have a family genetic history of hypertension will have a 10.5 times chance of experiencing hypertension faster than respondents who have genetically no hypertension. The table 5 below shows that value was obtained $(\mathrm{P}$-value $=$ $0.004<\alpha=0.05$ ) and OR 3,9, it can be concluded that respondents who have a poor lifestyle will have a chance as much as 3.9 times to experience hypertension faster than respondents who have a good lifestyle.

Table 4. Genetic Effect on the Occurrence of Hypertension

\begin{tabular}{llllllll}
\hline \multirow{2}{*}{ Genetic } & \multicolumn{3}{c}{ Hypertension } & \multicolumn{2}{c}{ Total } & \multirow{2}{*}{ P } \\
\cline { 2 - 7 } & \multicolumn{2}{c}{ Long } & New & & & \\
\cline { 2 - 7 } & $\mathrm{n}$ & $\%$ & $\mathrm{n}$ & $\mathrm{n}$ & $\%$ & & \\
\hline There is & 26 & 86,7 & 4 & 30 & 100 & 0,001 & 10,5 \\
No & 8 & 38,1 & 13,3 & 21 & 100 & & \\
\hline
\end{tabular}

Table 5. The Effect of Lifestyle on the Occurrence of Hypertension

\begin{tabular}{llllllll}
\hline \multirow{2}{*}{ Genetic } & \multicolumn{3}{c}{ Hypertension } & \multicolumn{2}{c}{ Total } & \multirow{2}{*}{ P } \\
& \multicolumn{2}{c}{ Long } & New & & & \\
\cline { 2 - 7 } & $\mathrm{n}$ & $\%$ & $\mathrm{n}$ & $\mathrm{n}$ & $\%$ & & \multirow{2}{*}{0,001} \\
\hline There is & 26 & 86,7 & 4 & 30 & 100 & 10,5 \\
No & 8 & 38,1 & 13,3 & 21 & 100 & & \\
\hline
\end{tabular}

\section{Discussion}

\section{Genetic Effect on the Incidence of Hypertension}

Based on the observations of researchers in the field, it was found that respondents who had hypertension family genetics and experienced old hypertension because their parents, namely the respondent's close family, were faster to experience hypertension, so that the respondents also experienced hypertension. Meanwhile, respondents who have a hypertensive family genetic and have recently experienced hypertension because the family with hypertension is a cousin of the respondent's parents so that the respondent has not had hypertension for a long time.

Furthermore, respondents who have family genetics are not hypertensive and have had hypertension for a long time because the respondent cannot stop unhealthy living habits such as eating fat and that respondents also experience hypertension more quickly. Meanwhile, respondents who have family genetics are not hypertensive and have recently experienced hypertension because the respondent always maintains a healthy lifestyle, so the respondent has not had hypertension for a long time.

Hypertension is a complex genetic disorder. Essential hypertension is usually related to genes and genetic factors, where many genes play a role in the development of hypertensive disorders. According to Martin Gómez, A. (2019), The role of genetic factors in the onset of hypertension is more in heterozygous twins (one egg) than in heterozygous (different eggs). A patient who has a genetic trait of primary (essential) hypertension, if left naturally without therapeutic intervention, together with his environment will cause his hypertension to develop and in about 30-50 years signs and symptoms will appear.

Previous research conducted by Anggraini 2009, 
in a study of factors related to the incidence of hypertension in patients who were treated at the Bangkinang Health Center Adult Polyclinic, the conclusion was that the results of the study were that there was a relationship between genetics and the incidence of hypertension in patients who were treated at the Adult Polyclinic at the Bangkinang Health Center (Anggraini, 2019) The results of this study were supported by research (Luft, F. C. 2020).

It was found that there was a significant relationship between genetics and the incidence of hypertension in patients who were treated at the adult polyclinic of Bangkinang Community Health Center for the period January to June 2008. Where the results of the study show that the majority of hypertensive patients have a family history of hypertension (65.2\%), and only a small proportion of nonhypertensive patients have a family history of hypertension (19.6\%).

\section{The Effect of Lifestyle of Hypertension}

Based on the observations of researchers in the field, the researcher found that respondents who have a good lifestyle and have had hypertension for a long time because their parents, namely the respondent's close family, have hypertension so that the respondent also has hypertension. Meanwhile, respondents who have a good lifestyle and have not had hypertension for a long time because respondents always try to maintain a healthy lifestyle.

One of the risky lifestyles for people with hypertension is drinking coffee which is dangerous for people with hypertension because caffeine can cause blood pressure to rise. Coffee consumption in this study was measured by asking the respondent whether he consumed coffee or not. Regular exercise three times a week and 10 minutach time can maximize blood pressure. Exercises, such as walking or cycling, have benefits for the cardiovascular system and can increase the risk of cardiovascular disease. Sports that are mostly done by students today are walking, running, cycling and other team sports such as futsal, basketball, and badminton. In this study, a person who does not regularly exercise and does not exercise at all is at risk of developing hypertension due to the influence of his lifestyle behavior, the results of this study who are not physically active suffer from hypertension.

Furthermore, respondents who have a poor lifestyle and have had hypertension for a long time because the respondent cannot stop an unhealthy lifestyle such as eating fat and so on so that the respondent also experiences hypertension. Meanwhile, respondents who have a poor lifestyle and have recently experienced hypertension because the respondent has cholesterol disease. The results of this study were supported by research (Malara 2014), it was found that the lifestyle was very influential in the occurrence of hypertension in the Kologan Health Center, Kalawat District, North Minahasa Regency, where the results of chi-square $((p)=0.04<0.05)$.

Lifestyle is an important factor affecting people's lives. An unhealthy lifestyle can be a cause of hypertension, for example, physical activity and stress (Kukobo, Y, et al, 2019). Lifestyle is an important factor affecting people's lives. An unhealthy lifestyle can be a cause of hypertension, for example, physical activity and stress (Kukobo, Y, et al, 2019). Excess intake of fat results in increased levels of fat in the body, especially cholesterol which causes weight gain so that blood volume experiences a greater increase in pressure (Valenzuela, P. L et al., 2020).

\section{Conclusion}

The existence of genetic and lifestyle influences on the occurrence of hypertension is evidenced by the value of $\mathrm{P}$-value $<\alpha=0.05$. Where is the genetic factor? with an OR result of 10.5 , it can be concluded that respondents who have a family genetic history of hypertension will have a 10.5 times chance of experiencing hypertension faster than respondents who do not have hypertension genetics. However, the lifestyle factor of the OR 3,9 result can be concluded that respondents who have a poor lifestyle will have a chance as much as 3.9 times to experience hypertension faster than respondents who have a good lifestyle. Both factors affect hypertension because both of the P-value values are below 0.05 .

\section{Acknowledgement}

To the health center or other related parties to be able to provide understanding to the community about a healthy lifestyle, eating nutritious food, regular healthy exercise such as not high in salt, stay away from alcohol so that hypertension can be avoided.

\section{Author Contribution and Competing Interest}

All of the authors contributed in collecting and analyzing the data, including preparing the manuscript. The author assures thet there is no conflict of interest in the activities and preparation of this report.

\section{Publisher's Note}


J-Kesmas: Jurna 1Fakultas Kesehatan Masyarakat (Indonesia Journal of Public Health) remains neutral with regard to jurisdictional claims in published institutional affiliation.

\section{Refference}

Asmadi, 2010. Teknik Prosedural Keperawatan: Konsep dan Aplikasi Kebutuhan Dasar Klien. Jakarta : Salemba Medika

Anggara Dwi, F H dan Prayitno N. 2013. Faktorfaktor yang Berhubungan dengan Tekanan Darah di Puskesmas Telaga Murni Cikarang Barat. Jakarta: Program Studi Kesehatan Masyarakat STIKES MH. Thamrin. Jurnal Ilmiah Kesehatan. Vol 5/ No. 1

Agromedia, 2013. Dampak dan Bahaya Penyakit Hipertensi. Agromedia Pustaka Jakarta.

Basha. 2011. Mengenai Penyakit Hipertensi, Diabetes, Storke dan Serangan Jantung. Cetakan Pertama. Jakarta : Keenbooks.

Dinas Kesehatan Kabupaten Aceh Barat, 2014, Profil Kesehatan Kabupaten Aceh Barat Tahun 2014, Meulaboh

Hull. 2010. Management Of Arterial Hypertension. WHO.Geneva

Kemenkes. 2013. "Pedoman Nasional PengendalianHipertensi”. Jakarta : Direktorat Jenderal Pengendalian Penyakit dan Penyehatan Lingkungan.

Malara. 2014. Hubungan Gaya Hidup Dengan Kejadian Hipertensi Di Puskesmas Kolongan Kecamatan Kalawat Kabupaten Minahasa Utara. ejournal keperawatan (e-Kp) Volume 2. Nomor 1. Februari 2014. Universitas Sam Ratulangi Manado

Profil Dinas Kesehatan Provinsi Aceh, 2013, Banda Aceh : Dinkes Prov

Puskesmas Meureubo, 2015 Pencatatan dan Pelaporan Puskesmas Meureubo

Riskesdas. 2013. Data dan Informasi Tahun 2013. Jakarta: Riset Kesehatan Dasar

Rawasiah. 2014. Hubungan faktor konsumsi makanan dengan kejadian hipertensi pada lansia di puskesmas pattingalloang. Fakultas Kesehatan Masyarakat Universitas Hasanuddin

Rindiastuti. 2011. Penyakit Kronik dan Degeneratif. Pusat Informasi dan Penerbitan Bagian Ilmu
Penyakit Dalam FK UI. Jakarta

Ridwan, M. 2010. Mengenal Mencegah, Mengatasi Silent Kiler Hipertensi. Jakarta : Pusaka Widyamara

Sugiharto,A. 2010. Faktor-Faktor Risiko Hipertensi Grade II Pada Masyarakat.Semarang: Diponegoro

Sugiyono. 2013. Metode Penelitian Kuantitatif dan Kualitatif dan $R \& D$. Alfabeta : Bandung

Sutisna. 2010. Perilaku Konsumen dan Strategi Pemasaran, Rosdakarya, Bandung, Hal 11 -22

World Health Organization (WHO, 2013). Data and Statisticsof Hipertensi. Diakses tanggal 2 September 2014

World Health Organization. (2020). OMS Hipertensión. Who. Retrieved from https://www.who.int/topics/hypertension/es/

Martin Gómez, A. (2019). En relación con «Documento de la Sociedad Española de Hipertensión-Liga Española para la Lucha contra la Hipertensión Arterial (SEH-LELHA) sobre las guías ACC/AHA 2017 de hipertensión arterial». Hipertensión $\quad y \quad$ Riesgo Vascular, 36(1), 53-54. https://doi.org/10.1016/j.hipert.2018.09.002

Tagle, R. (2018). Diagnóstico de Hipertensión arterial. Revista Médica Clínica Las Condes, 29(1), 12-20. https://doi.org/10.1016/j.rmclc.2017.12.005

Alfonso Prínce, J. C., Salabert Tortoló, I., Alfonso Salabert, I., Morales Díaz, M., García Cruz, D., \& Acosta Bouso, A. (2017). La hipertensión arterial: un problema de salud internacional. Rev. Medica Electron, 39(4), 987-994.

Putri, E. S., Marniati, A. H., \& Maifizar, A. (2020). The Influence of Hypertension and HighDensity Lipoprotein on the Diabetic Nephropathy Patients. prevalence, 2(10), 11.

Marniati, M., Putri, E. S., Sriwahyuni, S., Khairunnas, K., \& Duana, M. (2020). Knowledge Study, Income Level and SocioCulture of the Nutritional Status of a toddler. Journal of Nutrition Science, 1(2), 38-44.

Rodrigues, V. de O., Polisseni, F., Pannain, G. D., \& Carvalho, M. A. G. (2020). Genetics in human reproduction. Jornal Brasileiro de Reproducao Assistida. Sociedade Brasileira de Reproducao Assistida.

Melzer, D., Pilling, L. C., \& Ferrucci, L. (2020, 
February 1). The genetics of human aging. Nature Reviews Genetics. Nature Research. https://doi.org/10.1038/s41576-019-0183-6

Singh, R. K., Kumar, P., \& Mahalingam, K. (2017, February 1). Molecular genetics of human obesity: A comprehensive review. Comptes Rendus - Biologies. Elsevier Masson SAS. https://doi.org/10.1016/j.crvi.2016.11.007

Giuliani, C., Garagnani, P., \& Franceschi, C. (2018). Genetics of human longevity within an ecoevolutionary nature-nurture framework. Circulation Research, 123(7), 745772. https://doi.org/10.1161/CIRCRESAHA.118.312 56

Zilbermint, M., Hannah-Shmouni, F., \& Stratakis, C. A. (2019, March 1). Genetics of hypertension in African Americans and others of African descent. International Journal of Molecular Sciences. MDPI AG. https://doi.org/10.3390/ijms20051081

Luft, F. C. (2020). Molecular genetics of human hypertension. Current Opinion in Cardiology. Lippincott Williams and Wilkins. https://doi.org/10.1097/HCO.000000000000072 2

Baudrand, R., \& Vaidya, A. (2018, February 11). The low-renin hypertension phenotype: Genetics and the role of the mineralocorticoid receptor. International Journal of Molecular Sciences. MDPI AG. https://doi.org/10.3390/ijms19020546

Morrell, N. W., Aldred, M. A., Chung, W. K., Elliott, C. G., Nichols, W. C., Soubrier, F., ... Loyd, J. E. (2019, January 1). Genetics and genomics of pulmonary arterial hypertension. The European Respiratory Journal. NLM (Medline). https://doi.org/10.1183/13993003.01899-2018

Austin, E. D., \& Loyd, J. E. (2014). The genetics of pulmonary arterial hypertension. Circulation Research, 115(1), 189-200. https://doi.org/10.1161/CIRCRESAHA.115.303 40

Sarkar, T., \& Pal Singh, N. (2015, September 1). Epidemiology and genetics of hypertension. Journal of Association of Physicians of India. Journal of Association of Physicians of India.

Ma, L., \& Chung, W. K. (2017, January 1). The role of genetics in pulmonary arterial hypertension. Journal of Pathology. John Wiley and Sons Ltd. https://doi.org/10.1002/path.4833

Patel, R. S., Masi, S., \& Taddei, S. (2017, August 1). Understanding the role of genetics in hypertension. European Heart Journal. Oxford University Press. https://doi.org/10.1093/eurheartj/ehx273

Manosroi, W., \& Williams, G. H. (2018, December 24). Genetics of Human Primary Hypertension: Focus on Hormonal Mechanisms. Endocrine Reviews. Endocrine Society. https://doi.org/10.1210/er.2018-00071

Teixeira, S. K., Pereira, A. C., \& Krieger, J. E. (2018, June 1). Genetics of Resistant Hypertension: the Missing Heritability and Opportunities. Current Hypertension Reports. Current Medicine Group LLC 1. https://doi.org/10.1007/s11906-018-0852-4

Kokubo, Y., Padmanabhan, S., Iwashima, Y., Yamagishi, K., \& Goto, A. (2019, March 11). Gene and environmental interactions according to the components of lifestyle modifications in hypertension guidelines. Environmental Health and Preventive Medicine. BioMed Central Ltd. https:/doi.org/10.1186/s12199-019-0771-2

Kim, H., \& Andrade, F. C. D. (2019). Diagnostic status and age at diagnosis of hypertension on adherence to lifestyle 